\title{
REACTIONS OF 2-(2-LITHIOPHENYL)ETHYL CHLORIDE WITH IMINES AND ISOCYANATES. SYNTHESIS OF 1,2,3,4-TETRAHYDROISOQUINOLINES AND 3,4- DIHYDRO-1(2H)-ISOQUINOLINONES
}

\author{
J. A. Campbell, T. D. Greenwood, S. B. Hendi, M. S. Hendi, P. Nguyen, and J. F. Wolfe* \\ Department of Chemistry and the Harvey W. Peters Research Center for the Study of Parkinson's \\ Disease and Disorders of the Central Nervous System, Virginia Polytechnic Institute and State \\ University, Blacksburg, Virginia 24061-0212
}

\begin{abstract}
2-(2-Lithiophenyl)ethyl chloride 4 condenses with appropriately substituted imines 5a-c $\left(R_{1}=H, R_{2}=\right.$ aryl, $R_{3}=$ aryl, benzenesulfonyl) to give the corresponding 1,2disubstituted 1,2,3,4-tetrahydroisoquinolines 6 . Hindered imines $\mathbf{5 f - g}\left(R_{1}, R_{2}=\right.$ aryl) or $\mathrm{N}$-alkyl substituted imines $5 \mathrm{e}-\mathrm{f}$ fail to react, while those bearing $\alpha$-hydrogens react as acids with 4 , thus precluding formation of 6 . Treatment of 4 with phenanthridine affords 10,11-dihydrotribenzo[a,c,h]15bH-quinolizine $6 \mathrm{e}$ in a convenient one-step synthesis. 2-Substituted-3,4-dihydro-1(2H)-isoquinolinones 8 are obtained in good yields from the reaction of 4 with alkyl and aryl isocyanates 7.
\end{abstract}

\section{Introduction}

In connection with a search for convenient, new methods for the synthesis of isoquinolines and isoquinolinones, we were drawn to earlier reports of the preparation of indolines 1 (1) and phthalimidines $3(2)$ via reactions of 2 -lithiobenzyl chloride 2 with imines and isocyanates, respectively. The success of these reactions prompted us to investigate the feasibility of developing possible general syntheses of isoquinolines 6 and isoquinolinones 8 by similar reactions utilizing 2-(2-lithiophenyl)ethyl chloride 4. We now report on the scope and limitations of this synthetic method.<smiles>[Al]C1c2ccccc2CN1[Al]</smiles>

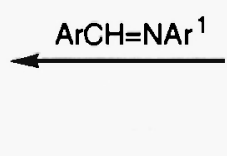<smiles>ClCc1ccccc1Cl</smiles><smiles>CCCCC(=O)O</smiles><smiles>O=C1C2=IC=CC=C2CN1[Ga]</smiles>

3 


\section{Results and Discussion}

Reaction of 4, generated by halogen-metal exchange from 2-(2-bromophenyl)ethyl chloride using 1.1 equiv of $\mathrm{n}-\mathrm{BuLi}$ in THF at $-78^{\circ} \mathrm{C}$, with $\mathrm{C}, \mathrm{N}$-diaryl imines $5 \mathrm{a}-\mathrm{c}$ afforded good yields (Table 1) of 1,2-diaryl-1,2,3,4-tetrahydroisoquinolines $6 \mathrm{a}-\mathrm{c}(3,4)$. Similar treatment of phenanthridine $5 \mathrm{~d}$<smiles>ClCCc1ccccc1I</smiles>

4

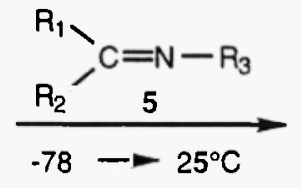

with 4 gave 10,11 -dihydrotribenzo[a,c,h]15bH-quinolizine $6 e$ in $81 \%$ yield. This facile synthesis of 6 e represents a significant improvement over that reported previously (5).

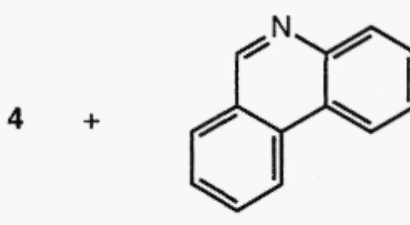

$5 d$<smiles>c1ccc2c(c1)CCN1c3ccccc3-c3ccccc3C21</smiles>

$6 e$

The success of the reaction of lithio derivative $\mathbf{4}$ with imines 5 is dependent on the nature of both the $\mathrm{C}$ - and $\mathrm{N}$-substituents of the imine. For example, the failure of imine $5 e\left(\mathrm{R}_{3}=\mathrm{CH}_{3}\right)$ to react with 4 demonstrates the necessity for an electron withdrawing $\mathrm{N}$-substituent to stablize the incipient negative charge on nitrogen resulting from attack of the phenyl carbanion at the imine carbon. The lack of reactivity of $5 f$ and $5 \mathrm{~g}\left(R_{1}=R_{2}=P h\right)$ towards 4 may be attributed to steric hindrance at the imine carbon. Imine $5 \boldsymbol{h}$, which contains $\alpha$-hydrogens, underwent deprotonation in the presence of 4 , leading ultimately to the formation of 1-phenyl-1-hexanone via alkylation of its $\alpha$-carbanion by $n$ butyl bromide formed in the initial metal-halogen exchange, followed by hydrolysis of the resulting C-alkylated imine. Although imines unsubstituted on nitrogen, i.e., with $R_{3}=H$, cannot be used in this methodology, tetrahydroisoquinolines 6 with $R_{3}=H$ can be obtained as illustrated by the condensation of 4 with $\mathrm{N}$-benzenesulfonyl imine $5 \mathrm{c}$, followed by reductive cleavage of the $\mathrm{PhSO}_{2}$ group of the resulting 2-benzenesulfonyl-1-phenyl-1,2,3,4-tetrahydroisoquinoline $6 \mathrm{c}$ with sodium naphthalenide in DME $(6)$ to afford 1-phenyl-1,2,3,4-tetrahydroisoquinoline $6 \mathrm{~d}(1,7)$ in $85 \%$ yield.

Treatment of a variety of alkyl and aryl isocyanates 7 with organolithium reagent 4 afforded 2substituted-3,4-dihydro-1(2H)-isoquinolinones 8 in yields of $71-85 \%$ (Table 2). This general reaction appears to be limited only by the availability of the isocyanate. The parent 3,4-dihydro$1(2 \mathrm{H})$-isoquinolinone $8 \mathrm{~b}$ was prepared by reductive cleavage of 2-(4-toluenesulfonyl)-3,4-dihydro- 
$1(2 \mathrm{H})$-isoquinolinone $8 \mathrm{e}$ in $\mathbf{5 1 \%}$ yield using a refluxing mixture of zinc and acetic and hydrochloric acids (8).

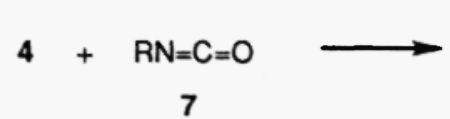<smiles>[R]N1CCc2ccccc2C1=O</smiles>

8

Table 1. Reactions of 2-(2-Lithiophenyl)ethyl Chloride 4 with Imines 5

\begin{tabular}{ccccccc} 
Imine & $\mathrm{R}_{1}$ & $\mathrm{R}_{2}$ & $\mathrm{R}_{3}$ & Product & Yield (\%) & $\mathrm{MP}^{\circ} \mathrm{C}$ \\
\hline $\mathbf{5 a}$ & $\mathrm{H}$ & $\mathrm{Ph}$ & $4-\mathrm{MePh}$ & $\mathbf{6 a}$ & 78 & $78-79^{\mathrm{a}}$ \\
$\mathbf{5 b}$ & $\mathrm{H}$ & $\mathrm{Ph}$ & $4-\mathrm{ClPh}$ & $\mathbf{6 b}$ & 64 & $110-111.5$ \\
$\mathbf{5 c}$ & $\mathrm{H}$ & $\mathrm{Ph}$ & $\mathrm{PhSO}_{2}$ & $\mathbf{6 c}$ & 67 & $102.5-103.5$ \\
$\mathbf{5 c}$ & $\mathrm{H}$ & $\mathrm{Ph}$ & $\mathrm{PhSO}_{2}$ & $\mathbf{6 d b}$ & 85 & $99.5-100.5^{\mathrm{c}}$ \\
$\mathbf{5 d}$ & & phenanthridine & & $6 \mathrm{e}$ & 81 & $154-157^{\mathrm{d}}$ \\
$\mathbf{5 e}$ & $\mathrm{H}$ & $\mathrm{Ph}$ & $\mathrm{Me}$ & $-\mathrm{e}$ & - & - \\
$\mathbf{5 f}$ & $\mathrm{Ph}$ & $\mathrm{Ph}$ & $\mathrm{Me}$ & $-\mathrm{f}$ & - & - \\
$\mathbf{5 g}$ & $\mathrm{Ph}$ & $\mathrm{Ph}$ & $4-\mathrm{MePh}$ & $\mathbf{5 g}$ & 100 & - \\
$5 \mathbf{5 h}$ & $\mathrm{Me}$ & $\mathrm{Ph}$ & $4-\mathrm{MePh}$ & $-\mathrm{g}$ & - & - \\
\hline
\end{tabular}

a Lit. (12) $\mathrm{mp} 74-75^{\circ} \mathrm{C}$. b From reductive cleavage of $6 \mathrm{c}$. c Lit. (7a) $\mathrm{mp} 98-100^{\circ} \mathrm{C}$. d Lit. (5) mp $155^{\circ} \mathrm{C}$. e Benzaldehyde (79\%) was obtained following aqueous workup. I Benzophenone was quantitatively recovered upon workup. g 1-Phenyl-1-hexanone $(62 \%)$ was isolated by column chromatography.

Table 2. Reactions of 2-(2-Lithiophenyl)ethyl Chloride 4 with Isocyanates 7

\begin{tabular}{|c|c|c|c|c|}
\hline Isocyanate & $\mathrm{R}$ & Product & Yield (\%) & $M P{ }^{\circ} \mathrm{C}$ \\
\hline $7 a$ & $\mathrm{Me}$ & $8 a$ & 85 & $a, b$ \\
\hline $7 b$ & $n-P r$ & $8 b$ & 72 & $-{ }^{a}$ \\
\hline $7 c$ & $\mathrm{i}-\mathrm{Pr}$ & $8 c$ & 75 & ${ }^{a}$ \\
\hline $7 d$ & $\mathrm{Ph}$ & $8 d$ & 74 & $104-105^{c}$ \\
\hline $7 e$ & 4-Tosyl & $8 e$ & 71 & $137-138.5$ \\
\hline $7 f$ & 4-Tosyl & $8 f \mathrm{~d} . e$ & 51 & $-^{a}$ \\
\hline
\end{tabular}

a Colorless liquid. b Ref. 13. c Lit. (13a) mp $101-103^{\circ} \mathrm{C}$. d From reductive cleavage of $8 \mathrm{e}$. e ${ }^{1} \mathrm{H}$ NMR data for $8 \mathrm{f}$ was consistent with that reported earlier (14). 


\section{Experimental}

Melting points were determined using a Thomas-Hoover melting point apparatus and are uncorrected. Elemental analyses were performed by Atlantic Microlab, Inc., Atlanta, Georgia. ${ }^{1 H}$ and ${ }^{13} \mathrm{C}$ NMR spectra were recorded on a Bruker WP-270 spectrometer using $\mathrm{CDCl}_{3}$ as solvent and TMS as the internal reference. Analytical TLC was performed on Eastman chromatogram sheets, type 13181 (silica gel) with fluorescent indicator. Flash chromatography refers to standard MPLC as described by Still (9) on silica gel 60 (230-400 mesh). All reagents were the best grade commercially available and were used without further purification. 2-(2-Bromophenyl)ethyl chloride was prepared as reported previously (10). n-BuLi was titrated prior to use with diphenylacetic acid as indicator (11).

\section{General Procedure for the Reaction of 2-(2-Lithiophenyl)ethyl Chloride 4 with Isocyanates and Imines}

To a magnetically stirred solution of 2-(2-bromophenyl)ethyl chloride $(1.10 \mathrm{~g}, 5.0 \mathrm{mmol})$ in $50 \mathrm{~mL}$ of anhydrous THF at $-78^{\circ} \mathrm{C}$ was added via syringe a solution of $\mathrm{n}-\mathrm{BuLi}$ in hexane $(5.5 \mathrm{mmol})$. The resulting solution was stirred at $-78^{\circ} \mathrm{C}$ under $\mathrm{N}_{2}$ for $30 \mathrm{~min}$, then a solution of the appropriate isocyanate or imine $(5.5 \mathrm{mmol})$ in THF $(5 \mathrm{~mL})$ was added dropwise. The reaction mixture was stirred at $-78^{\circ} \mathrm{C}$ for an additional $30 \mathrm{~min}$ and allowed to gradually warm to room temperature. After being stirred at ambient temperature overnight, the reaction mixture was quenched with $20 \mathrm{~mL}$ of a saturated $\mathrm{NH}_{4} \mathrm{Cl}$ solution and the THF was removed under reduced pressure at the rotary evaporator. Additional water $(50 \mathrm{~mL})$ was added, and the mixture was extracted with ether $(3 \times 75$ $\mathrm{mL})$. The combined ethereal layers were washed with water, dried $\left(\mathrm{MgSO}_{4}\right)$, filtered, and concentrated to give the crude product which was purified by flash column chromatography.

\section{2-(4-Chlorophenyl)-1-phenyl-1,2,3,4-tetrahydroisoquinoline 6b}

1H NMR: $\delta 7.11-7.24(\mathrm{~m}, 11 \mathrm{H}), 6.71(\mathrm{br} \mathrm{d}, 2 \mathrm{H}, \mathrm{J}=9.0 \mathrm{~Hz}), 5.73(\mathrm{~s}, 1 \mathrm{H}), 3.61-3.70(\mathrm{~m}, 1 \mathrm{H}), 3.36-$ $3.46(\mathrm{~m}, 1 \mathrm{H}), 2.86-2.90(\mathrm{~m}, 2 \mathrm{H}) .{ }^{13} \mathrm{C}$ NMR: $\delta 148.2,142.7,137.5,135.4,128.9,128.3,128.1,127.8$, 127.2, 126.9, 126.2, 122.4, 115.2, 63.0, 44.0, 28.0. Anal. Calcd for $\mathrm{C}_{21} \mathrm{H}_{18} \mathrm{NCl}$ : C, 78.86; $\mathrm{H}, 5.67$; $\mathrm{N}, 4.38$. Found: $\mathrm{C}, 78.92 ; \mathrm{H}, 5.69 ; \mathrm{N}, 4.37$.

\section{2-(Benzenesulfonyl)-1-phenyl-1,2,3,4-tetrahydroisoquinoline $6 \mathrm{c}$}

${ }^{1} \mathrm{H}$ NMR: $\delta$ 7.65-7.68 (br d, $\left.2 \mathrm{H}, \mathrm{J}=7.1 \mathrm{~Hz}\right) 7.37-7.43(\mathrm{~m}, 1 \mathrm{H}), 7.11-7.31(\mathrm{~m}, 9 \mathrm{H}), 6.95-7.00(\mathrm{~m}$, $2 \mathrm{H}$ ), $6.25(\mathrm{~S}, 1 \mathrm{H}$ ), 3.81 (dddd, $1 \mathrm{H}, \mathrm{J}=14.2,6.2,3.0,1.2 \mathrm{~Hz}$ ), 3.33 (ddd, $1 \mathrm{H}, \mathrm{J}=14.2,10.6,5.7 \mathrm{~Hz}$ ), 2.67 (ddd, $1 \mathrm{H}, \mathrm{J}=16.7,10.6,6.2 \mathrm{~Hz}$ ), 2.56 (ddd, $1 \mathrm{H}, \mathrm{J}=16.7,5.7,3.0 \mathrm{~Hz}$ ). ${ }^{13} \mathrm{C} \mathrm{NMR}: \delta 134.2$, 133.9, 132.2, 130.0, 128.7, 128.4, 128.3, 127.3, 127.1, 59.5, 39.3, 26.9. Anal. Calcd for $\mathrm{C}_{21} \mathrm{H}_{19} \mathrm{NO}_{2} \mathrm{~S}$ : C, 72.18; H, 5.48; N, 4.01. Found: C, 72.18; H, 5.52; N, 4.01.

2-(n-Propyl)-3,4-dihydro-1(2H)-isoquinolinone $8 \mathrm{~b}$

1H NMR: $\delta 8.07(\mathrm{~d}, 1 \mathrm{H}, \mathrm{J}=7.5 \mathrm{~Hz}), 7.28-7.41(\mathrm{~m}, 2 \mathrm{H}), 7.15(\mathrm{~d}, 1 \mathrm{H}, \mathrm{J}=7.2 \mathrm{~Hz}), 3.52(2$ 
overlapping t, $4 \mathrm{H}, \mathrm{J}=7.4,6.5 \mathrm{~Hz}$ ), $2.95(\mathrm{t}, 2 \mathrm{H}, \mathrm{J}=6.5 \mathrm{~Hz}$ ), 1.65 (sextet, $2 \mathrm{H}, \mathrm{J}=7.4 \mathrm{~Hz}$ ), $0.96(\mathrm{t}, 3 \mathrm{H}, \mathrm{J}$ $=7.4 \mathrm{~Hz}$ ). ${ }^{13} \mathrm{C}$ NMR: $\delta 164.1,137.9,131.2,129.6,128.0,126.8,126.6,48.9,46.0,28.0,20.8,11.2$. Anal. Calcd for $\mathrm{C}_{12} \mathrm{H}_{15} \mathrm{NO}: \mathrm{C}, 76.15 ; \mathrm{H}, 7.99 ; \mathrm{N}, 7.40$. Found: $\mathrm{C}, 76.53 ; \mathrm{H}, 8.11 ; \mathrm{N}, 7.40$.

\section{2-(i-Propyl)-3,4-dihydro-1(2H)-isoquinolinone $8 \mathrm{c}$}

1H NMR: $\delta 8.07$ (br d, $1 \mathrm{H}, \mathrm{J}=7.5 \mathrm{~Hz}$ ), 7.28-7.41 (m, 2H), 7.15 (br d, $1 \mathrm{H}, \mathrm{J}=7.5 \mathrm{~Hz}$ ), 5.09 (heptet, $1 \mathrm{H}, \mathrm{J}=6.8 \mathrm{~Hz}), 3.41(\mathrm{t}, 2 \mathrm{H}, \mathrm{J}=6.5 \mathrm{~Hz}), 2.92(\mathrm{t}, 2 \mathrm{H}, \mathrm{J}=6.5 \mathrm{~Hz}), 1.10\left(\mathrm{~d}, 6 \mathrm{H}, \mathrm{J}=6.8 \mathrm{~Hz}\right.$ ). ${ }^{13} \mathrm{C} \mathrm{NMR:} \delta$ 163.6, 137.7, 131.2, 130.0, 128.2, 126.8, 126.5, 43.7, 38.8, 28.4, 19.6. Anal. Calcd for $\mathrm{C}_{12} \mathrm{H}_{15} \mathrm{NO}$ : C, $76.15 ; H, 7.99 ; N, 7.40$. Found: $C, 76.14 ; H, 8.18 ; N, 7.14$.

\section{2-(4-Toluenesulfonyl)-3,4-dihydro-1(2H)-isoquinolinone $8 \mathrm{e}$}

1H NMR: $\delta 7.97$ (br d, 3H, J = 8.3 Hz), 7.46 (dd, $1 \mathrm{H}, \mathrm{J}=7.4,6.3 \mathrm{~Hz}$ ), 7.31 (br d, 3H, J = 8.3 Hz), $7.21\left(\mathrm{br} \mathrm{d}, 1 \mathrm{H}, \mathrm{J}=7.4 \mathrm{~Hz}\right.$ ), $4.22(\mathrm{t}, 2 \mathrm{H}, \mathrm{J}=6.2 \mathrm{~Hz}), 3.11(\mathrm{t}, 2 \mathrm{H}, \mathrm{J}=6.2 \mathrm{~Hz}), 2.40(\mathrm{~s}, 3 \mathrm{H}) .{ }^{13} \mathrm{C}$ NMR: $\delta$ 163.3, 144.6, 139.2, 136.3, 133.3, 129.3, 129.0, 128.4, 128.2, 127.3, 44.7, 28.8, 21.5. Anal. Calcd for $\mathrm{C}_{16} \mathrm{H}_{15} \mathrm{NO}_{3} \mathrm{~S}: \mathrm{C}, 63.77 ; \mathrm{H}, 5.02 ; \mathrm{N}, 4.65$. Found: $\mathrm{C}, 63.84 ; \mathrm{H}, 5.01 ; \mathrm{N}, 4.69$.

\section{1-Phenyl-1,2,3,4-tetrahydroisoquinoline 6d}

Sodium $(0.46 \mathrm{~g}, 20 \mathrm{mmol})$ was added to a solution of naphthalene $(2.56 \mathrm{~g}, 20 \mathrm{mmol})$ in $40 \mathrm{~mL}$ of anhydrous DME in a $100 \mathrm{~mL}$ flask which was then capped with a rubber septrum. The mixture was stirred at room temperature until the green color persisted (ca. $2 \mathrm{~h}$ ). A solution of $6 \mathrm{c}(1.75 \mathrm{~g}, 5.0$ $\mathrm{mmol}$ ) in $10 \mathrm{~mL}$ of DME was injected via syringe and the mixture was stirred for $1 \mathrm{~h}$ then quenched by the addition of $1 \mathrm{~mL}$ of water. The organic solvent was distilled on the rotary evaporator and 50 $\mathrm{mL}$ of water was added to the residue. The mixture was extracted with $3 \times 50 \mathrm{~mL}$ portions of $\mathrm{CHCl}_{3}$ and the combined extracts were washed with water, dried $\left(\mathrm{MgSO}_{4}\right)$ and concentrated. The residue was chromatographed (gradient elution, $0-100 \%$ EtOAc in $\mathrm{CHCl}_{3}$ ) to yield $0.78 \mathrm{~g}(85 \%)$ of $6 \mathrm{~d}$ as a white solid, $\mathrm{mp} 98-100^{\circ} \mathrm{C}$. Recrystallization form hexane afforded $6 \mathrm{~d}$ as delicate white needles, $\mathrm{mp}$ $99.5-100.5^{\circ} \mathrm{C}$.

\section{3,4-Dihydro-1(2H)-isoquinolinone $8 f$}

2-(4-Toluenesulfonyl)-3,4-dihydro-1 $(2 \mathrm{H})$-isoquinolinone $8 \mathrm{e}(1.51 \mathrm{~g}, 5.0 \mathrm{mmol})$ was dissolved in a mixture of $20 \mathrm{~mL}$ of glacial $\mathrm{AcOH}$ and $2 \mathrm{~mL}$ of concentrated $\mathrm{HCl}$ by warming. After heating to near reflux, zinc dust $(6.54 \mathrm{~g}, 100 \mathrm{mmol})$ was added cautiously. The reaction mixture was then heated under reflux for $4 \mathrm{~h}$ during which time two additional $2.0 \mathrm{~mL}$ aliquots of concentrated $\mathrm{HCl}$ were added. After cooling the reaction mixture to room temperature, the unreacted zinc was filtered. The filtrate was concentrated to a pale yellow viscous oil to which was added $100 \mathrm{~mL}$ of water. The aqueous mixture was extracted with $3 \times 75 \mathrm{~mL}$ portions of ether and the combined ethereal extracts were washed with water and dried $\left(\mathrm{MgSO}_{4}\right)$. Concentration then afforded a pale yellow oil which was chromatographed. Elution with $\mathrm{CH}_{2} \mathrm{Cl}_{2}$ afforded first $0.31 \mathrm{~g}(50 \%)$ of p-thiocresol as a white solid, $\mathrm{mp} 43-45^{\circ} \mathrm{C}$ followed by $0.19(13 \%)$ of unreacted $8 \mathrm{e}$. The eluent was changed to EtOAc and $0.38 \mathrm{~g}(51 \%)$ of $8 \mathrm{f}$ was collected as a pale yellow oil. 


\section{References}

(1) C. K. Bradsher and D. A. Hunt, J. Org. Chem., 46, 327 (1981).

(2) W. E. Parham, L. D. Jones and Y. A. Sayed, J. Org. Chem., 41, 1184 (1976).

(3) 1-Aryl-1,2,3,4-tetrahydroisoquinolines have been prepared by treatment of $N$-benzylidene- $\beta$ (2-bromophenyl)ethylamines with $\mathrm{n}$-BuLi at $-100^{\circ} \mathrm{C}$, see ref. 1 .

(4) For the preparation of 1-substituted-3,4-dihydroisoquinolines by the reaction of 4 with nitriles see: W. E. Parham, C. K. Bradsher and D. A. Hunt, J. Org. Chem., 43, 1606 (1978) and D. J. Jakiela, D. Helquist and L. D. Jones, Org. Synth., 62, 74 (1984).

(5) G. Van Binst, R. B. Baert and R. Salsmans, Synth. Commun. 3(1), 59 (1973).

(6) S. Ji, L. B. Gortler, A. Waring, A. Battisti, S. Bank and W. D. Closson, J. Am. Chem. Soc. 89, 5311 (1967).

(7) (a) G. Van Binst and R. B. Baert, J. Heterocycl. Chem. 12, 1165 (1975); (b) G. Toth, L. Hazai, G. Deak and H. Duddeck, Justus Liebigs Ann. Chem. 1103 (1978).

(8) D. Klamann and G. Hofbauer, Chem. Ber. 86, 1246 (1953).

(9) W. C. Still, M. Kahn and A. Mitra, J. Org. Chem., 43, 2923 (1978).

(10) J. Ponton, P. Helquist, P. C. Conrad and P. L. Fuchs, J. Org. Chem. 46, 118 (1981).

(11) W. G. Kofron and L. M. Baclawski, J. Org. Chem. 41, 1879 (1976).

(12) E. Hoft, A. Rieche and H. Schultze, Justus Liebigs Ann. Chem. 697, 181 (1966).

(13) (a) E. Hoft and H. Schultze, J. Prakt. Chem. 32, 12 (1966); (b) R. A. Henry and C. A. Heller, J. Lumin. 4, 105 (1971); (c) V. Simanek, V. Preininger, S. Hegerova and F. Santavy, Collect. Czech. Chem. Commun. 37, 2746 (1972).

(14) M. Mori, K. Chiba and Y. Ban, J. Org. Chem. 43, 1684 (1978).

Received April 23, 1996 